\title{
Co-authorship analysis of the speleothem proxy-climate community: working together to tackle the big problems
}

\author{
Micheline L. Campbel1 ${ }^{*}$, John N. Callow ${ }^{1}$, Gavan S. McGrath ${ }^{2}$, and Hamish A. McGowan ${ }^{3}$ \\ ${ }^{1}$ School of Agriculture and Environment, The University of Western Australia, 35 Stirling Highway, Crawley WA 6009, Australia \\ ${ }^{2}$ Ishka Solutions, 6009, Nedlands WA, Australia \\ ${ }^{3}$ School of Earth and Environmental Sciences, The University of Queensland, St Lucia QLD 4072, Brisbane, Australia
}

\begin{abstract}
Understanding the environmental context of speleothem palaeo-climate proxies is fundamental to their interpretation. We analyse four methodological approaches to accomplish this: stalactite discharge analysis, proxy/process tracer studies, discharge modelling, and geophysics. Datamining produced citation data sets that reflected these methodological subdisciplines. Social network analysis is used to examine co-authorship within and between these sub-disciplines, and between the joint methodological community and the broader speleothem proxy climate community. Members of the sub-disciplines have become more connected to one another over time, and to members of the other sub-disciplines. High degrees of connectivity between and within communities allows for the rapid and efficient adoption of new ideas and methods, and will enable the community to effectively tackle emerging complex problems.
\end{abstract}

Keywords: paleoclimatology, co-authorship, speleothem

Received 14 November 2017; Revised 10 March 2018; Accepted 25 March 2018

Citation: Campbell M.L., Callow J.N., McGrath G.S. and McGowan H.A., 2018. Co-authorship analysis of the speleothem proxy-climate community: working together to tackle the big problems. International Journal of Speleology, 47 (2), 165-172. Tampa, FL (USA) ISSN 0392-6672 https://doi.org/10.5038/1827-806X.47.2.2159

\section{INTRODUCTION}

The speleothem-derived palaeo-climate proxy community (SPCPC) seeks to improve understanding of past climates through the interpretation of climate sensitive proxies in stalagmites. This necessitates better understanding of the environmental context, including climate impacts (from the micro-scale (cave environment) to the macro-scale (large weather systems and climate patterns)) and groundwater hydrology (McDermott, 2004; Fairchild et al., 2006a; Lachniet, 2009; Fairchild \& Baker, 2012). We analysed four methodological approaches to achieve this, which are broadly grouped into; stalactite discharge analysis, proxy/process tracer studies (hereinafter "tracer studies"), discharge modelling, and geophysics (Table 1). Nonetheless, the SPCPC faces ongoing challenges related to the common assumption of stationarity in how the proxy data respond to changes in climate, i.e. that the proxies will exhibit the same behaviour in response to changes in climate over time (Gedalof, 2002; Jones \& Mann, 2004; Bradley et al., 2010; Baker et al., 2013; Moerman et al., 2014).

As systems-based approaches have become prevalent in the environmental sciences, many disciplines have advocated inter-, trans- and multi-disciplinarity (Steele \& Stier, 2000; Klein, 2008; Bark et al., 2016). Choi and Pak, (2006) note that while 'inter-,' 'trans-,' and 'multi-disciplinarity' are commonly used terms, they are poorly defined, applied ambiguously, and used interchangeably. Here, we use the term "interdisciplinary" to refer to any instance of co-authorship between scientists from different disciplines, where co-authorship is defined as collaboration between unique authors in a published piece of work.

Social network analysis methods have been developed to measure collaborative behaviour. These methods are based on the study of social structure using graph theory, and originate in sociology (Scott, 1988). Coauthorship networks have been used to represent acquaintanceship and research collaboration effort, and thereby the sharing of ideas (Newman, 2001, 2004; Huang \& Chang, 2011). Co-authorship social network analysis (C-SNA) has been used for strategic planning of research and development (Morel et al., 2009), to investigate the relationship between coauthorship and h-index (McCarty et al., 2013), to study inter-disciplinarity (Huang et al., 2011), and to investigate the structure of different fields of study (Grossman, 2002; Newman, 2004; Zare-Farashbandi 
et al., 2014). At the individual level, McCarty et al. (2013) showed that scientific impact as measured by the h-index increases when authors collaborate with as many co-authors as possible.

We use C-SNA to investigate co-authorship within methodological sub-disciplines of the SPCPC, between these sub-disciplines, and across the whole community from 1996 to 2017. This has implications for the capability of the community to identify and address emerging complex problems. We address three specific questions:

1) Have the populations of the methodological subdisciplines become more connected over time?

2) Have the methodological sub-disciplines become more connected to one another? Is there a trend towards inter-disciplinarity?

3) Has the whole speleothem palaeo-climate community moved towards inter-disciplinarity?

Table 1. Strengths and weaknesses of methods used to contextualise stalagmite proxy climate records.

\begin{tabular}{|c|c|c|c|c|}
\hline Method & Strengths & Weaknesses & Key Applications & References \\
\hline $\begin{array}{l}\text { Stalactite } \\
\text { discharge } \\
\text { analysis }\end{array}$ & $\begin{array}{c}\text { Common method; } \\
\text { Rugged technology; } \\
\text { capable of long-term } \\
\text { and remote deployment; } \\
\text { information about physical } \\
\text { (drip) hydrology. }\end{array}$ & $\begin{array}{l}\text { Without tracer data } \\
\text { can't quantify impact of } \\
\text { subsurface processes on } \\
\text { proxy record. }\end{array}$ & $\begin{array}{l}\text { Commonly used to support } \\
\text { palaeo-climate reconstructions. } \\
\text { Includes discharge response } \\
\text { to precipitation, effective } \\
\text { infiltration, etc. }\end{array}$ & $\begin{array}{c}\text { Baldini et al., 2006; Fairchild et } \\
\text { al., 2006a; Genty \& Deflandre, } \\
\text { 1998; Hu et al., 2008; Mahmud } \\
\text { et al., 2016; Markowska et al., } \\
2015\end{array}$ \\
\hline $\begin{array}{l}\text { Proxy/Process } \\
\text { tracer studies }\end{array}$ & $\begin{array}{l}\text { Quantitative results: } \\
\text { event times, mixing, } \\
\text { transmission time. }\end{array}$ & $\begin{array}{l}\text { Can be conservative; } \\
\text { false breakthrough } \\
\text { signatures; approvals } \\
\text { and social licence for } \\
\text { using artificial tracers; } \\
\text { natural variability of } \\
\text { isotope input; karst } \\
\text { complexity complicates } \\
\text { signal. }\end{array}$ & $\begin{array}{c}\text { Landscape-scale karst } \\
\text { hydrology and small scale karst } \\
\text { drip hydrology; tracer studies } \\
\text { - including stable isotopes, } \\
\text { radio isotopes, trace element } \\
\text { concentrations and processes } \\
\text { such as source - precipitation- } \\
\text { infiltration-drip discharge; } \\
\text { dissolution processes and } \\
\text { disequilibrium/kinetic isotope } \\
\text { fractionation. }\end{array}$ & $\begin{array}{l}\text { Bottrell \& Atkinson, 1992; } \\
\text { Bradley et al., 2010; Callow } \\
\text { et al., 2014; Cuthbert et al., } \\
\text { 2014; Fairchild et al., 2006b; } \\
\text { Friedrich \& Smart, 1982; Fuller } \\
\text { et al., 2008; Gunn, 1974; Jex } \\
\text { et al., 2012; Kogovsek \& Petric, } \\
\text { 2014; Pitty, 1966; Polk et al., } \\
\text { 2012; Poulain et al., 2015; } \\
\text { Treble et al., 2013, } 2005\end{array}$ \\
\hline $\begin{array}{l}\text { Discharge } \\
\text { modelling }\end{array}$ & $\begin{array}{c}\text { Extend limited } \\
\text { observational records; infer } \\
\text { subsurface processes that } \\
\text { affect dripwater behaviour } \\
\text { and chemistry. }\end{array}$ & $\begin{array}{l}\text { Simplify reality, may not } \\
\text { capture complexity of } \\
\text { the physical system; not } \\
\text { always physically-based. }\end{array}$ & $\begin{array}{l}\text { Commonly used in association } \\
\text { with drip monitoring and tracer } \\
\text { experiments, recently a greater } \\
\text { emphasis on modelling isotopic } \\
\text { values in dripwaters. }\end{array}$ & $\begin{array}{l}\text { Arbel et al., 2010; Bradley et } \\
\text { al., 2010; Cuthbert et al., 2014; } \\
\text { Fairchild, et al., 2006b; Tooth } \\
\text { \& Fairchild, 2003; Treble et al., } \\
\text { 2013; Wackerbarth et al., } 2010\end{array}$ \\
\hline Geophysics & $\begin{array}{l}\text { Non-invasive, high spatial } \\
\text { resolution (incl. 3D); image } \\
\text { physical structure. }\end{array}$ & $\begin{array}{l}\text { Cannot image at the } \\
\text { pore-scale; limited } \\
\text { resolution at depth; } \\
\text { artefacts caused by (for } \\
\text { example) large cavities } \\
\text { limit resolution. }\end{array}$ & $\begin{array}{l}\text { Limited applications at } \\
\text { stalactite-scale settings. }\end{array}$ & $\begin{array}{l}\text { Al-fares et al., 2002; Campbell } \\
\text { et al., 2017; Carrière et al., } \\
\text { 2013; Roth \& Nyquist, 2003; } \\
\text { Valois et al., 2010; van Schoor, } \\
\text { 2002; Zhou et al., } 2000\end{array}$ \\
\hline
\end{tabular}

\section{METHODS}

We apply CSNA to citation data obtained by data mining the Web of Science - Core Collection $\left(26^{\text {th }}\right.$ of May 2017) using keywords (Morel et al., 2009). Keyword searches were applied for the four identified methodological approaches; stalactite discharge analysis ("speleothem AND hydrology NOT model", $\mathrm{n}=48$ ), tracer studies ("speleothem AND tracer", $\mathrm{n}=20$ ), geophysics ("karst AND geophysics", $\mathrm{n}=76$ ) and discharge modelling ("speleothem AND hydrology AND model", $\mathrm{n}=27$ ). Methodological approaches and keywords were chosen through a review of the literature, and to capture a sufficiently large portion of the community in order to make analyses possible (respectively). Consequently, a broader search term for geophysics was used as "speleothem AND geophysics' only returned one article. The databases are used to attribute sub-disciplines to the authors, and authors are assumed to have published in multiple disciplines if they are found in multiple databases. There was just one paper which appeared in two databases, and those authors were attributed to (at least) two disciplines. We also extracted a broader community set using "speleothem AND climate" ( $\mathrm{n}=860)$, and this was combined with the citations sourced to investigate the methodological approaches to form an overall SPCPC community database (duplicates between the two datasets were included but classified as part of the methodological subset). The Web of Science - Core Collection was chosen over other archives as it does not contain unpublished papers. Citations were exported in ".bib" file format. Citation data were analysed cumulatively at time-steps of 5 years between 1996 (the earliest entry for any of the search terms in the Web of Science- Core Collection) and 2017. Note that the final time step was 6 years. Bin size was a parsimonious choice to reflect change over time. The decision was made to present data in cumulative time-steps because discrete time windows do not adequately reflect the nature of the collaboration networks, in that they become more connected over time. The choice of bin size also impacts the analysis of discrete time windows. If authors were to collaborate extensively in the first time period, but not the second, it would appear as if they are not connected (or even present in the network) in the second time period, when in reality they may still be collaborating on unpublished work during this time. See Supplementary Figure 1 for an analysis of co-authorship in the sub-disciplines in discrete time windows.

Data analysis and network construction were undertaken in $R$ using the bibtex and igraph, packages (Csardi \& Nepusz, 2006; Francois et al., 2017; R Core Team, 2017). Files were parsed to extract the unique author name, and names were considered to consist of one first initial and a surname. The term 'unique 
author' refers to the unique authors present in the database. Efforts were made to ensure correct attribution of authorship to each parsed unique author. Instances of coauthorship between unique authors were recorded in an adjacency matrix, which was then converted into a graph of co-authorship. All network graphs were rendered in Gephi (Gephi, 2016), see Fig. 1 for an example of network components and how to interpret them.

Networks were evaluated using the average degree and the presence or absence and relative size of a giant component. The average degree is the mean number of coauthors that each unique author has, where higher average degree
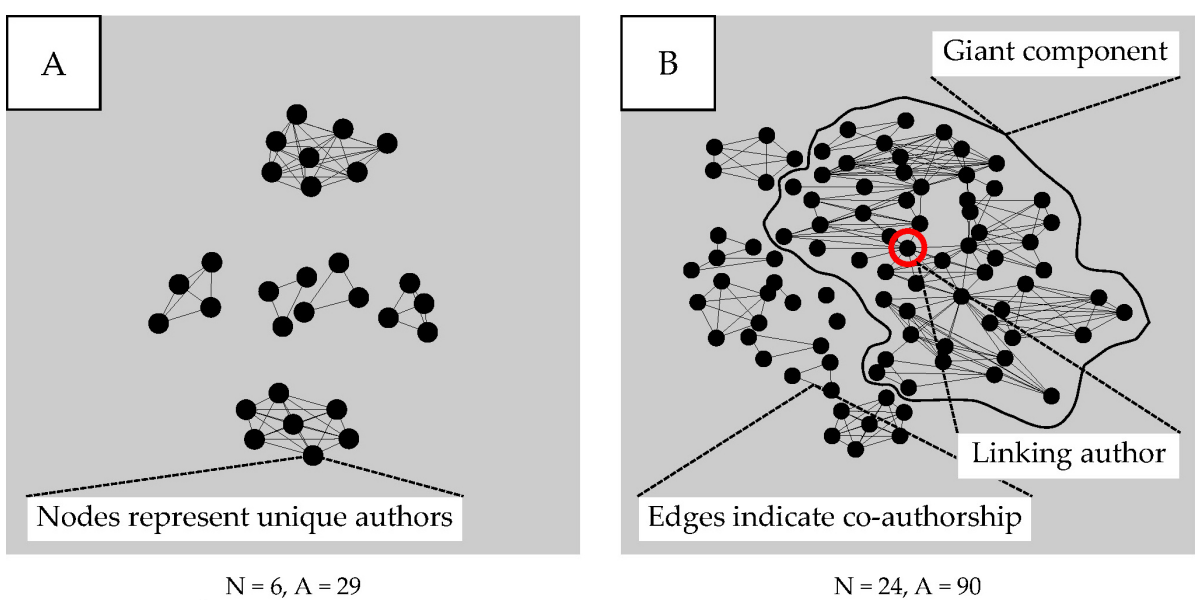

Fig. 1. An example of network features. Nodes represent authors, and connecting lines (edges) indicate that authors have collaborated. $1 \mathrm{~A}$ does not include a giant component, as the largest connected subgraph is the product of a single publication. 1B shows a giant component (circled) which is made up of unique authors collaborating over $>1$ publication/s. The red circle in 1B denotes a 'linking author' who is the only connection between different parts of the network. The position of nodes in the graph and the length of edges do not signify anything.

means that information propagates more readily through the network (Newman, 2001). The term 'giant component' refers to the largest subgraph (connected part of the network) (Holme et al., 2002). Here, we further restrict the definition to exclude subgraphs which are only comprised of the unique authors of one paper. Therefore, in Fig. 1, which shows two example networks and their key features, $1 \mathrm{~A}$ does not include a giant component as the largest subgraph is the product of just one instance of collaboration (i.e. all of the authors who collaborated on one paper are connected). Figure 1B includes a giant component made up of unique authors collaborating in several different instances. Not all unique authors in the giant component are directly connected by co-authorship, but as members of the giant component they may still benefit from the easier sharing of ideas through the connected part of the network.

The full citation dataset and $R$ scripts are in the Supplementary Material. Analysis was conducted on each: a) method database (see Section By discipline), b) the combined method database (see Section Combined discipline), and c) the overall SPCPC community database (see Section Whole community).

\section{RESULTS AND DISCUSSION}

\section{By discipline}

The CSNA identifies that the SPCPC methodological sub-disciplines have grown in both the number of unique authors and their level of connectivity, as shown by the increase in the average degree over time (Fig. 2), though some subtle but important differences are evident between the sub-disciplines. The stalactite discharge analysis sub-community is the second largest network, growing exponentially from 10 unique authors in 2001 to 213 in 2017. The discharge analysis network became more connected during this time, as the average degree increased from 4.8 to 7.47 between 2001 and 2017. The average degree of the discharge analysis network in 2017 was second only to that of the discharge modelling community. By 2017, $177 / 213(83 \%)$ unique authors were part of the giant component, this is an increase from 58/249 (23\%) in 2011, when the giant component was first observed.

The tracer study community is the youngest and smallest sub-community. The first citation found in the Web of Science Core Collection database was published in 2004, but the discipline has grown consistently from 13 authors in 2006 to 80 in 2017 . Co-authorship has not been as pronounced within the tracer community, although it has increased over time. A small giant component had formed by 2011 (10/42 authors) but by 2017 this giant component comprised just 18 of the 80 authors $(22 \%)$. However, these 18 are very well connected which reflects the relatively high average degree which increased from 4 in 2001 to 5.25 in 2017. Although members of the giant component were in the analysis in 2006, the giant component was not observed until 2011.

The discharge modelling community grew from 3 authors in 2001 to 107 in 2017. During this time coauthorship also increased - the average degree grew from 3.1 to 8.15 (the highest observed average degree of any of the disciplines). By 2011 a giant component was observed (12/30 authors), and by 2017 the giant component included 38/107 authors and a secondary subgraph had formed which included 29/107 authors. In both the giant component and the subgraph there are linking authors (two in each) who act as the only link between different groups of authors in the network (see also Fig. 1B). These linking authors clearly have a role as influencers, and are likely established members of the community.

The geophysics community is the largest and least well-connected community, although its size is an artefact of the broader search terms applied. Despite this, the average degree is consistently low relative to the other disciplines (4.17 in 2017). A giant component had formed by 2011 , although it included just $9 \%$ of the community (12/137). By 2017 this had increased to $12 \% 27 / 232)$. Due to the relative lack of connectivity in the geophysics community there are no standout linking authors until 2017 when one member of the giant component had published with every other member. 

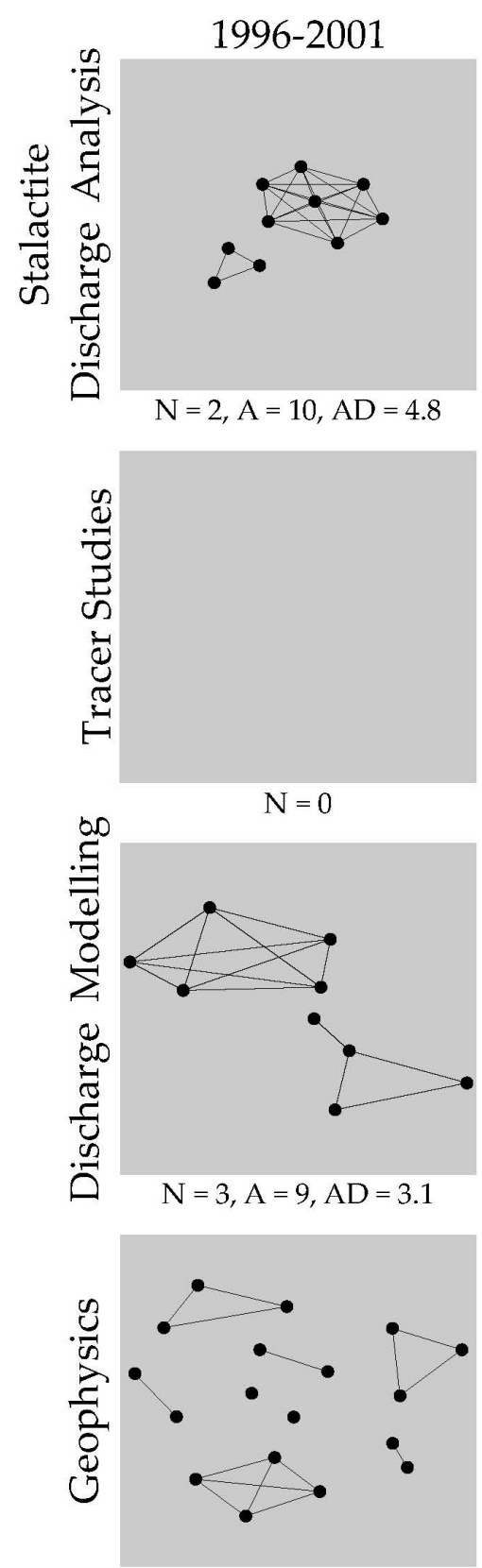

$\mathrm{N}=8, \mathrm{~A}=18, \mathrm{AD}=1.7$
1996-2006
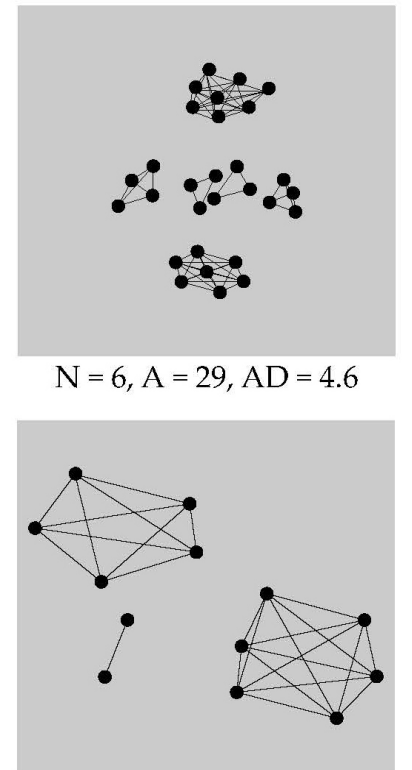

$\mathrm{N}=3, \mathrm{~A}=13, \mathrm{AD}=4$
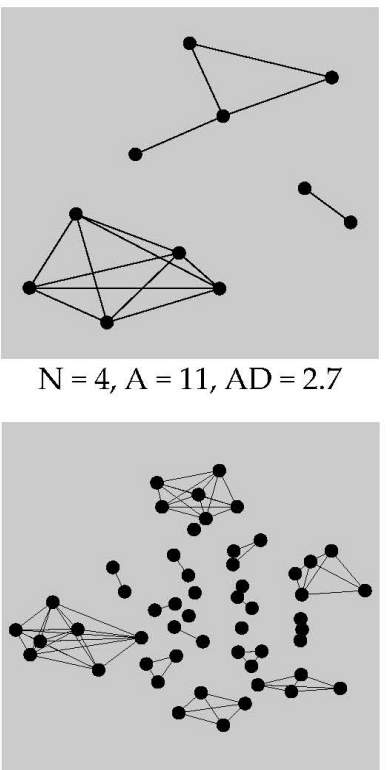

$\mathrm{N}=24, \mathrm{~A}=53, \mathrm{AD}=2.8$
1996-2011

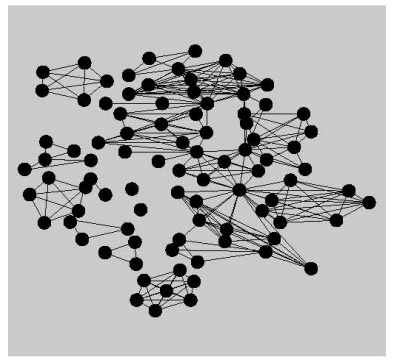

$\mathrm{N}=24, \mathrm{~A}=90, \mathrm{AD}=5.5$

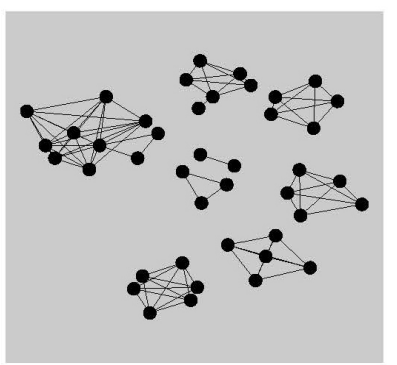

$\mathrm{N}=11, \mathrm{~A}=42, \mathrm{AD}=4.3$

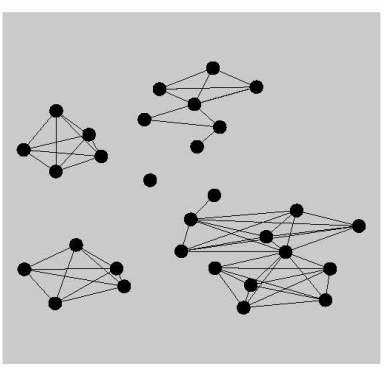

$\mathrm{N}=11, \mathrm{~A}=30, \mathrm{AD}=4.1$

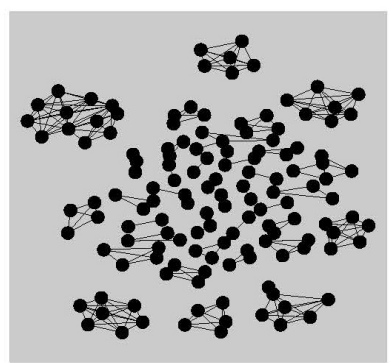

$\mathrm{N}=49, \mathrm{~A}=137, \mathrm{AD}=3.3$
1996-2017

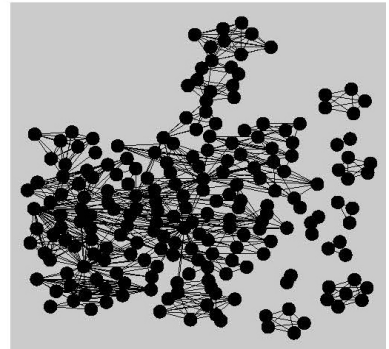

$\mathrm{N}=48, \mathrm{~A}=213, \mathrm{AD}=7.5$

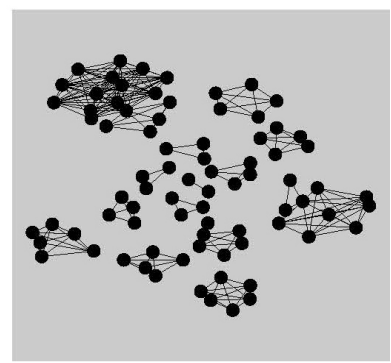

$\mathrm{N}=20, \mathrm{~A}=80, \mathrm{AD}=5.5$

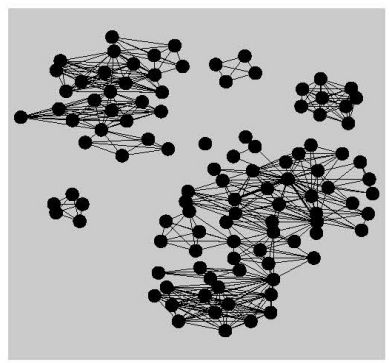

$\mathrm{N}=27, \mathrm{~A}=107, \mathrm{AD}=8.2$

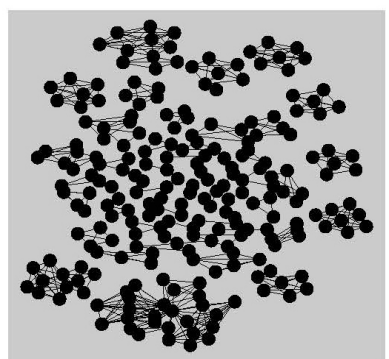

$\mathrm{N}=76, \mathrm{~A}=232, \mathrm{AD}=4.2$

Fig. 2. Co-authorship networks for each methodological sub-community over time, where $\mathrm{N}$ is the number of publications, $\mathrm{A}$ is the number of unique authors, and $\mathrm{AD}$ is the average degree (the mean number of co-authors that each unique author has).

\section{Combined disciplines}

Since 2001, the four sub-disciplines have become increasingly connected, as shown in Fig. 3 and by the increase in the average degree.

A giant component was present in 2001, which included 9 of 33 authors (27\%). This remained stable through to 2006 (although the percentage of total authors in the giant component had fallen to $9 \%$ ). By 2011 the giant component included 95 of 275 authors (34\%), and by 2017 it included 269 of 563 authors (48\%). The stalactite discharge analysis and discharge modelling disciplines are the most interdisciplinary. In 2001, all authors from these two disciplines were part of either the giant component or a multi-disciplinary subgraph. In 2017 they continued to represent the largest proportion of the giant component, with 253 of the 268 authors in the giant component publishing in stalactite discharge analysis, discharge modelling, or both. There is a growing trend towards authors publishing in multiple sub-disciplines. In 2001, four authors had published in two sub-disciplines, this increased to five in 2006 , 22 in 2011 and 46 in 2017. By 2011, one author had published in three sub-disciplines. This increased to 11 by 2017.

In 2017 geophysics dominated outside of the giant component (221 authors), followed by tracer studies (34 authors), then stalactite discharge analysis (19 authors), and modelling (12 authors). Although outside the giant component, inter-disciplinarity still occurred in subgraphs, with 33 authors publishing either across different disciplines or with co-authors from different disciplines. This includes six authors who themselves published across two different disciplines and an additional author who published across 3 different disciplines.

While authors publishing across different subdisciplines are not necessarily linking authors as per our definition, it is likely that they may have been linking authors in the past and have played 

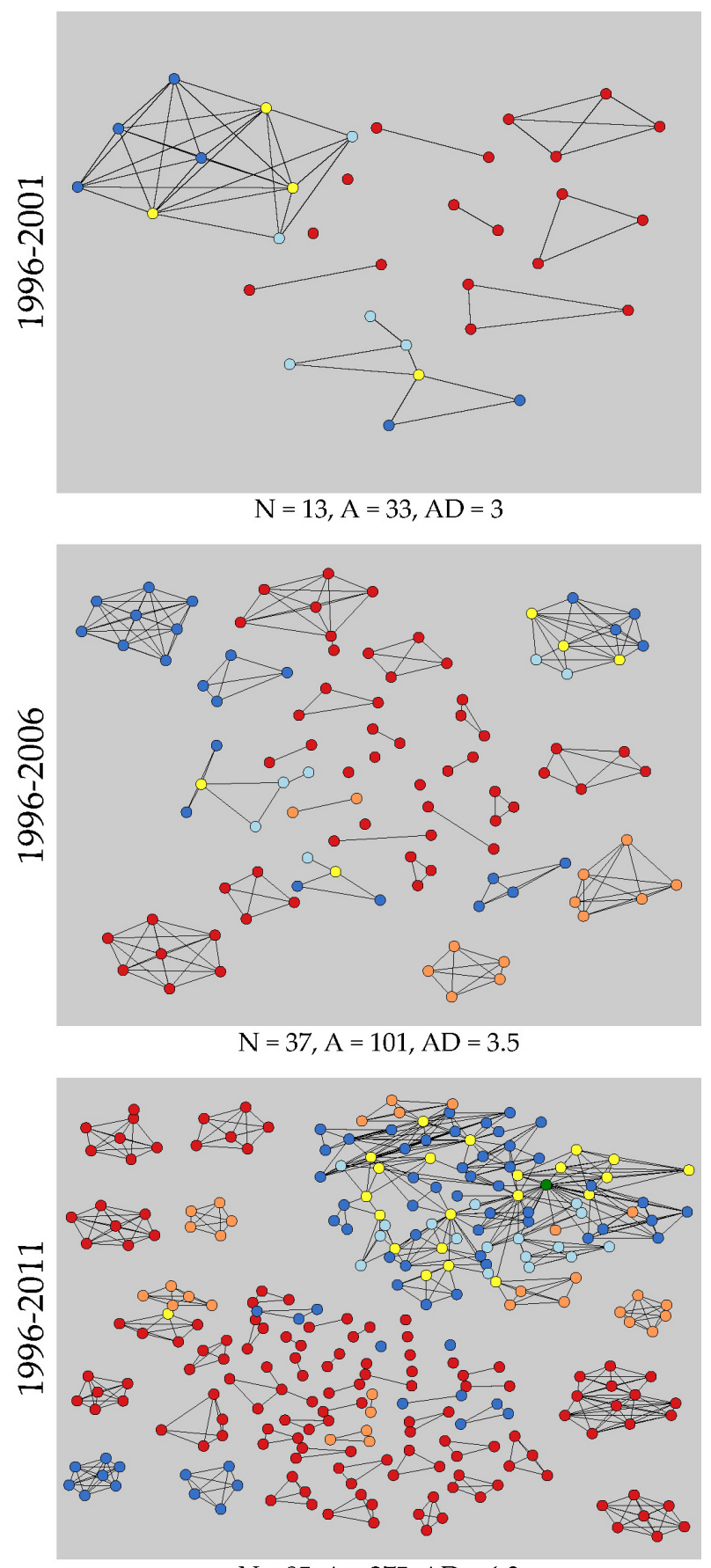

$\mathrm{N}=95, \mathrm{~A}=275, \mathrm{AD}=4.3$

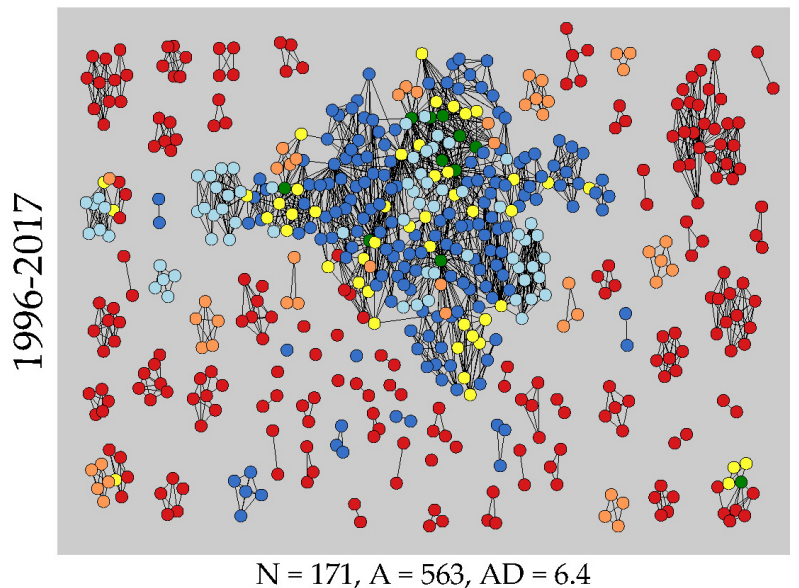

Fig. 3. Combined co-authorship network, with unique authors colour-coded by the sub-discipline they published within. Stalactite discharge analysis is dark blue, tracer studies is orange, discharge modelling is light blue, and geophysics is red. Authors that have published within two sub-disciplines are yellow, and those that have published within three sub-disciplines are green. key roles in sharing information and methods, owing to their central positions in the giant component, and their experience in applying different methods. Since collaborating implies acquaintanceship and the communication of ideas, by publishing with co-authors from different disciplines, authors are exposed to different methods, approaches, and ideas (Huang et al., 2011; Newman, 2001, 2004).

\section{Whole community}

The rate of publication, and by inference, the broader SPCPC continues to grow. While the proportion of publications in the method-derived citation database which was used for the analyses in sections $B y$ discipline and Combined disciplines ("the subset") has not increased relative to the whole community (Fig. 4), co-authorship analysis shows that the authors in the subset are linked to the broader community, and that the broader community is itself highly connected (Fig. 5). Of 2433 unique authors in the broader community, 563 (23\%) of them were found in the subset. A giant component included 2122 (87\%) of the total unique authors, and authors from the subset made up $417 / 2122$ (20\%) of that giant component. Therefore, while co-authors in the subset database are well connected to one another (see section Combined disciplines), they are not as well-connected to the broader speleothem climate community. Note that the broad search terms used to define the broader community is likely to have included authors that have referred to the applications of speleothems in palaeo-climate science as a general comment. As such, the shortfall between the proportion of the subset in the whole community and in the giant component is not surprising.

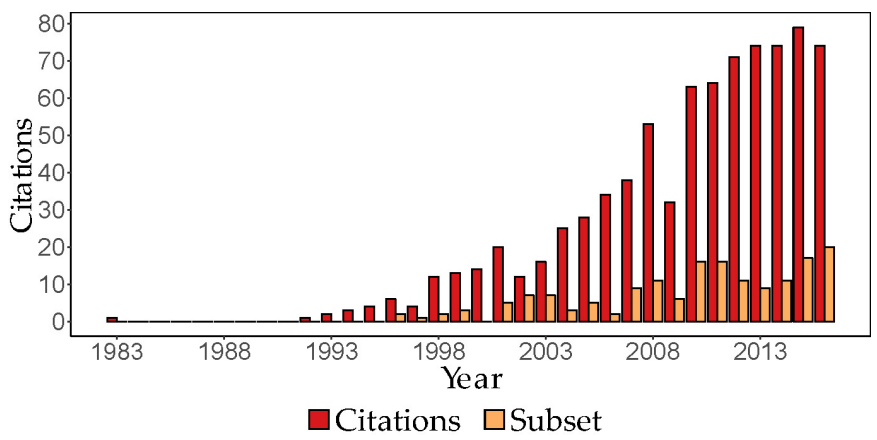

Fig. 4. Citations data-mined from the web of science. The citations that make up the method-based subset are orange and the whole citation network is red.

\section{CONCLUSIONS}

Since 2001, the methodological sub-disciplines identified in this analysis have become more connected. This is most notable in the stalactite discharge analysis, tracer studies, and discharge modelling disciplines. Increasing levels of coauthorship has implications for the propagation of information through the community, and the growth of the community, as authors with high levels of coauthorship are statistically more likely to add new coauthors to the network (Barabási \& Albert, 1999).

The methodological sub-disciplines have become more connected to one another over time. Again this 

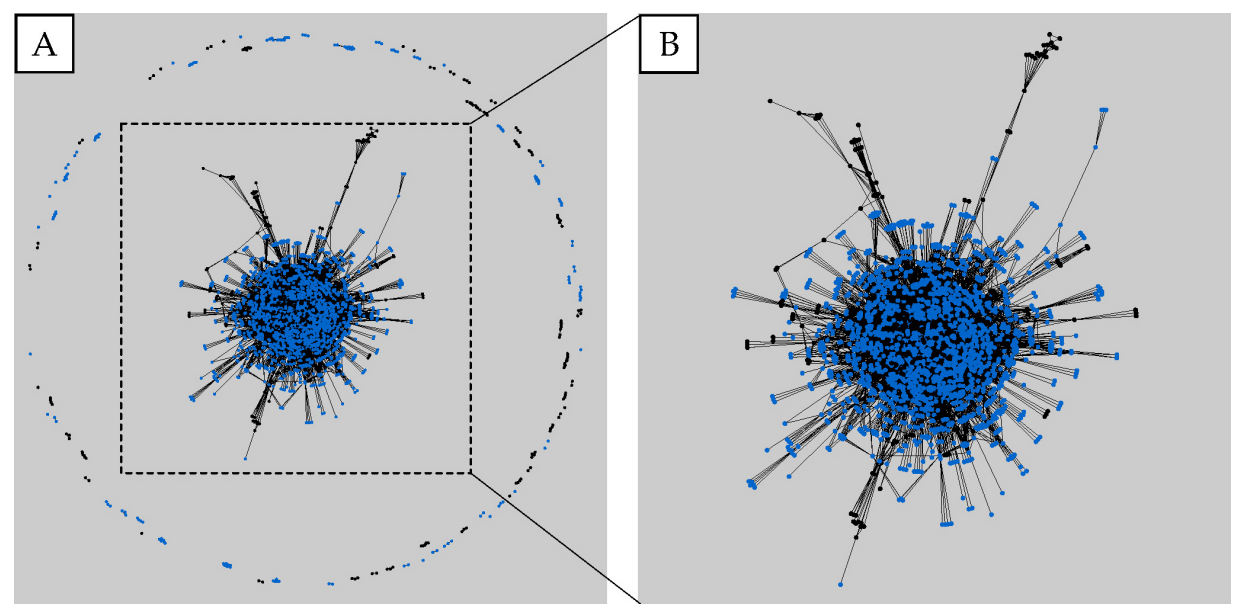

Fig. 5. The methodological subset (black) and its connections with the broader community (blue).

Figure $5 \mathrm{~B}$ is an enlargement of the giant component in the network.

behaviour was most common in the discharge analysis, tracer studies and discharge modelling disciplines. There was also an increase in the number of authors publishing across multiple disciplines. The high level of cohesiveness and inter-disciplinarity means that the community has improved scope to tackle complex problems, and is able to quickly adopt and share new technologies and methodologies. The absence of geophysics from the giant component until after 2011 is surprising considering that the method is broadly applied in karst science, and that geophysicists were consistently well represented in the database. Its addition to the giant component of the network after 2011 is an indicator that this technology has begun to be adopted by the community. We may expect the use of geophysics to become more common due to the high levels of co-authorship in the broader SPCPC, and therefore easy pathways of knowledge sharing.

The broader SPCPC is highly connected, and the subdisciplines are represented in the giant component. This means that, while many of the citations in the broader palaeo-climate community were not represented in the analysis of inter-disciplinarity, it is likely that they have access to the knowledge and expertise to adopt a diverse range of methods.

The speleothem palaeo-climate proxy community has become increasingly well-connected, and increasingly inter-disciplinary. While there remains a large part of the community that has not adopted any of the common methods to contextualise speleothem proxy climate records, the high degree of co-authorship between the members of the methodological subdisciplines and the community at large indicates that it is likely that the broader community will a) adopt these approaches, and b) become more interdisciplinary over time, or c) become aware of these approaches through enhanced dissemination of ideas through a more integrated speleothem palaeo-climate proxy community. An interesting subject for future research is the speleothem palaeo-climate proxy community's self-perception of collaborative behaviour between different sub-disciplines. This could use social science methods (such as interviews and surveys) to establish the methodological approaches of these subdisciplines and where authors position themselves within or across them.

\section{ACKNOWLEDGMENTS}

This research is supported by an Australian Government Research Training Program (RTP) Scholarship. MLC also received funding from Snowy Hydro Ltd. and through an Australian Institute of Nuclear Science and Engineering Postgraduate Research Award. Thanks to two anonymous reviewers for their constructive comments.

\section{REFERENCES}

Al-fares W., Bakalowicz M., Guérin R. \& Dukhan M., 2002 - Analysis of the karst aquifer structure of the Lamalou area (Hérault, France) with ground penetrating radar. Journal of Applied Geophysics, 51 (2): 97-106. https://doi.org/10.1016/S0926-9851(02)00215-X

Arbel Y., Greenbaum N., Lange J. \& Inbar M., 2010 Infiltration processes and flow rates in developed karst vadose zone using tracers in cave drips. Earth Surface Processes and Landforms, 35 (14): 1682-1693. https://doi.org/10.1002/esp.2010

Baker A., Bradley C. \& Phipps S.J., 2013 - Hydrological modeling of stalagmite $\delta^{18} \mathrm{O}$ response to glacialinterglacial transitions. Geophysical Research Letters, 40 (12): 3207-3212.

https://doi.org/10.1002/grl.50555

Baldini J.U.L., McDermott F. \& Fairchild I.J., 2006 Spatial variability in cave drip water hydrochemistry: Implications for stalagmite paleoclimate records. Chemical Geology, 235 (3-4): 390-404. https://doi.org/10.1016/j.chemgeo.2006.08.005

Barabási A. \& Albert R., 1999 - Emergence of Scaling in Random Networks. Science, 286: 509-512.

https://doi.org/10.1126/science.286.5439.509

Bark R.H., Kragt M.E. \& Robson B.J., 2016 - Evaluating an interdisciplinary research project: Lessons learned for organisations, researchers and funders. International Journal of Project Management, 34 (8): 1449-1459. https://doi.org/10.1016/j.ijproman.2016.08.004

Bottrell S.H. \& Atkinson T.C., 1992 - Tracer study of flow and storage in the unsaturated zone of a karstic limestone aquifer. In: Hotzl H. \& Werner A. (Eds.), Tracer hydrology: Proceedings of the sixth international symposium on water tracing. Rotterdam, Balkerna, p. 207-211.

Bradley C., Baker A., Jex C.N. \& Leng M.J., 2010 Hydrological uncertainties in the modelling of cave drip-water $\delta^{18} \mathrm{O}$ and the implications for stalagmite palaeoclimate reconstructions. Quaternary Science Reviews, 29 (17-18): 2201-2214.

https://doi.org/10.1016/j.quascirev.2010.05.017 
Callow N., McGowan H., Warren L. \& Speirs J., 2014 Drivers of precipitation stable oxygen isotope variability in an alpine setting, Snowy Mountains, Australia. Journal of Geophysical Research: Atmospheres, 119 (6): 3016-3031. https://doi.org/10.1002/2013JD020710

Campbell M.L., Callow J.N., McGrath G.S. \& McGowan H.A., 2017 - A multimethod approach to inform epikarst drip discharge modelling: Implications for palaeo-climate reconstruction. Hydrological Processes, 31 (26): 47344747. https://doi.org/10.1002/hyp.11392

Carrière S., Chalikakis K., Sénéchal G., Danquigny C. \& Emblanch C., 2013 - Combining Electrical Resistivity Tomography and Ground Penetrating Radar to study geological structuring of karst Unsaturated Zone. Journal of Applied Geophysics, 94: 31-41.

https://doi.org/10.1016/j.jappgeo.2013.03.014

Choi B. \& Pak A., 2010 - Multidisicplinarity, interdisciplinarity and transdisciplinarity in health research, services, education and policy: 1. Definitions, objectives, and evidence of effectiveness. European Journal of Immunology, 40 (12): 3299-3300. https://doi.org/10.1002/eji.201090065

Csardi G. \& Nepusz T., 2006 - The igraph software package for complex network research. InterJournal, Complex Systems, 1695 (5): 1-9.

Cuthbert M.O., Baker A., Jex C.N., Graham P.W., Treble P.C., Andersen M.S. \& Acworth I.R., 2014 - Drip water isotopes in semi-arid karst: Implications for speleothem paleoclimatology. Earth and Planetary Science Letters, 395: 194-204.

https://doi.org/10.1016/j.eps1.2014.03.034

Fairchild I.J. \& Baker A., 2012 - Speleothem science: From process to past environments ( ${ }^{\text {st }} \mathrm{Ed}$.). Chichester: Wiley-Blackwell, $432 \mathrm{p}$.

https://doi.org/10.1002/9781444361094

Fairchild I.J., Smith C.L., Baker A., Fuller L., Spötl C., Mattey D. \& McDermott F., 2006a - Modification and preservation of environmental signals in speleothems. Earth-Science Reviews, 75 (1-4): 105-153.

https://doi.org/10.1016/j.earscirev.2005.08.003

Fairchild I.J., Tuckwell G.W., Baker A. \& Tooth A.F., 2006b - Modelling of dripwater hydrology and hydrogeochemistry in a weakly karstified aquifer (Bath, UK): Implications for climate change studies. Journal of Hydrology, 321 (1-4): 213-231.

https://doi.org/10.1016/j.jhydrol.2005.08.002

Francois R., Hornik K., Koohafkan M. \& McLean M.W., 2017 - "bibtex" Bibtex Parser. Retrieved from https:// github.com/romainfrancois/bibtex\%0D

Friedrich H. \& Smart P.L., 1982 - The Classification of Autogenic Percolation Waters in Karst Aquifers: A Study in G.B. Cave, Mendip Hills, England. Proceedings, University of Bristol, Speleological Society, 16 (2): 143-159.

Fuller L., Baker A., Fairchild I.J., Spötl C., Marca-Bell A., Rowe P. \& Dennis P.F., 2008 - Isotope hydrology of dripwaters in a Scottish cave and implications for stalagmite palaeoclimate research. Hydrology and Earth System Sciences Discussions, 5 (2): 547-577. https://doi.org/10.5194/hessd-5-547-2008

Gedalof Z., 2002 - A multi-century perspective of variability in the Pacific Decadal Oscillation: new insights from tree rings and coral. Geophysical Research Letters, 29 (24): 2204. https://doi.org/10.1029/2002GL015824

Genty D. \& Deflandre G., 1998-Drip flow variations under a stalactite of the Père Noel cave (Belgium). Evidence of seasonal variations and air pressure constraints. Journal of Hydrology, 211 (1-4): 208-232.

https://doi.org/10.1016/S0022-1694(98)00235-2
Gephi 2016 - Gephi Graph Visualization and Manipulation. Grossman J.W., 2002 - Patterns of collaboration in mathematical research. SIAM News, 35 (9): 14-16.

Gunn J., 1974 - A model of the karst percolation system of waterfall swallet, Derbyshire. Transactions of the British Cave Research Association, 1: 159-164.

Holme P., Kim B.J., Yoon C.N. \& Han S.K., 2002 - Attack vulnerability of complex networks. Physical Review E, 65 (5): 56109.

https://doi.org/10.1103/PhysRevE.65.056109

Hu C., Henderson G., Huang J., Chen Z. \& Johnson K.R., 2008 - Report of a three-year monitoring programme at Heshang Cave, Central China. International Journal of Speleology, 37 (3): 143-151. https://doi.org/10.5038/1827-806X.37.3.1

Huang M.-H. \& Chang Y.-W., 2011 - A study of interdisciplinarity in information science: using direct citation and co-authorship analysis. Journal of Information Science, 37 (4): 369-378. https://doi.org/10.1177/0165551511407141

Jex C.N., Mariethoz G., Baker A., Graham P., Andersen M.S., Acworth I., Edwards, N., \& Azcurra C., 2012 - Spatially dense drip hydrological monitoring and infiltration behaviour at the Wellington Caves, South East Australia. International Journal of Speleology, 41 (2): 283-296.

https://doi.org/10.5038/1827-806X.41.2.14

Jones P. \& Mann M., 2004 - Climate over past millennia. Reviews of Geophysics, 42 (2): RG2002.

https://doi.org/10.1029/2003RG000143

Klein J.T., 2008 - Evaluation of interdisciplinary and transdisciplinary research. American Journal of Preventive Medicine, 35 (2): S116-S123. https://doi.org/10.1016/j.amepre.2008.05.010

Kogovsek J. \& Petric M., 2014 - Solute transport processes in a karst vadose zone characterized by long-term tracer tests (the cave system of Postojnska Jama, Slovenia). Journal of Hydrology, 519 : 1205-1213.

https://doi.org/10.1016/j.jhydrol.2014.08.047

Lachniet M.S., 2009 - Climatic and environmental controls on speleothem oxygen-isotope values. Quaternary Science Reviews, 28 (5-6): 412-432.

https://doi.org/10.1016/j.quascirev.2008.10.021

Mahmud K., Mariethoz G., Baker A., Treble P.C., Markowska M. \& McGuire E., 2016 - Estimation of deep infiltration in unsaturated limestone environments using cave lidar and drip count data. Hydrology and Earth System Sciences, 20 (1): 359-373.

https://doi.org/10.5194/hess-20-359-2016

Markowska M., Baker A., Treble P.C., Andersen M.S., Hankin S., Jex C.N.,Tadros, C.V. \& Roach R., 2015 Unsaturated zone hydrology and cave drip discharge water response: Implications for speleothem paleoclimate record variability. Journal of Hydrology, 529 : 662-675. https://doi.org/10.1016/j.jhydrol.2014.12.044

McCarty C., Jawitz J.W., Hopkins A. \& Goldman A., 2013 - Predicting author h-index using characteristics of the co-author network. Scientometrics, 96 (2): 467483. https://doi.org/10.1007/s11192-012-0933-0

McDermott F., 2004 - Palaeo-climate reconstruction from stable isotope variations in speleothems: a review. Quaternary Science Reviews, 23 (7-8): 901-918. https://doi.org/10.1016/j.quascirev.2003.06.021

Moerman J.W., Cobb K.M., Partin J.W., Meckler A.N., Carolin S.A., Adkins J.F., Lejau, S., Malang, J., Clark, B. \& Tuen A.A., 2014 - Transformation of ENSO-related rainwater to dripwater $\delta^{18} \mathrm{O}$ variability by vadose water mixing. Geophysical Research Letters, 41 (22): $7907-$ 7915. https://doi.org/10.1002/2014GL061696 
Morel C.M., Serruya S.J., Penna G.O. \& Guimarães R., 2009 - Co-authorship network analysis: A powerful tool for strategic planning of research, development and capacity building programs on neglected diseases. PLoS Neglected Tropical Diseases, 3 (8): e501.

https://doi.org/10.1371/journal.pntd.0000501

Newman M.E.J., 2001 - The structure of scientific collaboration networks. Proceedings of the National Academy of Sciences of the USA, 98 (2): 404-409. https://doi.org/10.1073/pnas.021544898

Newman M.E.J., 2004 - Coauthorship networks and patterns of scientific collaboration. Proceedings of the National Academy of Sciences of the USA, 101: 52005205. https://doi.org/10.1073/pnas.0307545100

Pitty A.F., 1966 - An Approach to the Study of Karst Water: University of Hull Occasional Papers in Geography No. In: H.R. Wilkinson (Ed.). University of Hull Publications, Hulll, 70 p.

Polk J.S., van Beynen P. \& Wynn J., 2012 - An isotopic calibration study of precipitation, cave dripwater, and climate in west-central Florida. Hydrological Processes, 26 (5): 652-662.

https://doi.org/10.1002/hyp.8169

Poulain A., Rochez G., Bonniver I. \& Hallet V., 2015 - Stalactite drip-water monitoring and tracer tests approach to assess hydrogeologic behavior of karst vadose zone: case study of Han-sur-Lesse (Belgium). Environmental Earth Sciences, 74 (12): 7685-7697. https://doi.org/10.1007/s12665-015-4696-9

$\mathrm{R}$ Core Team 2017 - R: A language and environment for statistical computing. Vienna, Austria. Retrieved from https://www.r-project.org/

Roth M.J.S. \& Nyquist J.E., 2003 - Evaluation of multielectrode earth resistivity testing in karst. ASTM Geotechnical Testing Journal, 26 (2): 1-12.

Scott J., 1988 - Trend report: Social network analysis. Sociology, 22 (1): 109-127. https://doi.org/10.1177/0038038588022001007

Steele T.W. \& Stier J.C., 2000 - The impact of interdisciplinary research in the environmental sciences: a forestry case study. Journal of the American Society for Information Science, 51 (5): 476-484. https://doi.org/10.1002/(SICI) 10974571(2000)51:5\%3C476::AID-ASI8\%3E3.0.CO;2-G
Tooth A.F. \& Fairchild I.J., 2003 - Soil and karst aquifer hydrological controls on the geochemical evolution of speleothem-forming drip waters, Crag Cave, southwest Ireland. Journal of Hydrology, 273 (1-4): 51-68. https://doi.org/10.1016/S0022-1694(02)00349-9

Treble P.C., Bradley C., Wood A., Baker A., Jex C.N., Fairchild I.J., Gagan M.K., Cowley J. \& Azcurra C., 2013 - An isotopic and modelling study of flow paths and storage in Quaternary calcarenite, SW Australia: implications for speleothem paleoclimate records. Quaternary Science Reviews, 64 : 90-103. https://doi.org/10.1016/j.quascirev.2012.12.015

Treble P.C., Chappell J., Gagan M., Mckeegan K.D. \& Harrison T.M., 2005 - In situ measurement of seasonal $\delta^{18} \mathrm{O}$ variations and analysis of isotopic trends in a modern speleothem from southwest Australia. Earth and Planetary Science Letters, 233 (1-2): 17-32.

https://doi.org/10.1016/j.eps1.2005.02.013

Valois R., Bermejo L., Guérin R., Hinguant S., Pigeaud R. \& Rodet J., 2010 - Karstic morphologies identified with geophysics around Saulges caves (Mayenne, France). Archaeological Prospection, 17 (3): 151-160. https://doi.org/10.1002/arp

van Schoor M., 2002 - Detection of sinkholes using $2 D$ electrical resistivity imaging. Journal of Applied Geophysics, 50 (4): 393-399. https://doi.org/10.1016/S0926-9851(02)00166-0

Wackerbarth A., Scholz D., Fohlmeister J. \& Mangini A., 2010 - Modelling the $\delta^{18} O$ value of cave drip water and speleothem calcite. Earth and Planetary Science Letters, 299 (3-4): 387-397. https://doi.org/10.1016/j.eps1.2010.09.019

Zare-Farashbandi F., Geraei E. \& Siamaki S., 2014 Study of co-authorship network of papers in the Journal of Research in Medical Sciences using social network analysis. Journal of Research in Medical Sciences: The Official Journal of Isfahan University of Medical Sciences, 19 (1): 41-46.

https://www.ncbi.nlm.nih.gov/pmc/articles/ PMC3963322/?tool=pmcentrez

Zhou W., Beck B.F. \& Stephenson J.B., 2000 - Reliability of dipole-dipole electrical resistivity tomography for defining depth to bedrock in covered karst terranes. Environmental Geology, 39 (7): 760-766. https://doi.org/10.1007/s002540050491 